\title{
The impact of customer experience on customer behavior intention use in social media com- merce, an extended expectation confirmation model: An empirical study
}

\author{
I Wayan Kandi Wijaya ${ }^{a}$, Anak Agung Gede Rai ${ }^{b}$ and Taqwa Hariguna ${ }^{c^{*}}$
}

${ }^{a, b}$ Department of Management Ngurah Rai University, Indonesia

${ }^{c}$ Department Information System, College of Amikom Purwokerto, Indonesia

\begin{tabular}{|c|c|}
\hline CHRONICLE & ABSTRACT \\
\hline $\begin{array}{l}\text { Article history: } \\
\text { Received: June 11, } 2019 \\
\text { Received in revised format: June } \\
292019 \\
\text { Accepted: July 4, } 2019 \\
\text { Available online: } \\
\text { July 4, } 2019 \\
\text { Keywords: } \\
\text { Customer experience } \\
\text { Expectation confirmation model } \\
\text { s-commerce }\end{array}$ & $\begin{array}{l}\text { This paper aims to develop an integrated model designed to predict and explain a customer behav- } \\
\text { ior intention use of s-commerce based on the concepts of customer experience (CE) and expecta- } \\
\text { tion confirmation model (ECM). This paper proposes a comprehensive model to synthesize the } \\
\text { essence of CE and ECM to describe customer behavior intention use of s-commerce. The partici- } \\
\text { pants are from } 311 \text { users of s-commerce as the final sample. Structural equation modeling is ap- } \\
\text { plied to demonstrate the stability of the proposed model and the results of hypotheses testing. This } \\
\text { paper finds that costumer experience significantly influenced perceived usefulness, expectation } \\
\text { and satisfaction, while the perceived usefulness and expectation simultaneously influenced cus- } \\
\text { tomer satisfaction. Expectation also significantly influences motivator of perceived usefulness. } \\
\text { Meanwhile perceived usefulness and satisfaction both significantly influence behavior intention } \\
\text { use of s-commerce directly. There are some limitations in this study which should be improved in } \\
\text { the future. Extended ECM is evaluated in a country setting, which limits generalizations. }\end{array}$ \\
\hline
\end{tabular}

(C) 2019 by the authors; licensee Growing Science, Canada

\section{Introduction}

Nowadays, globalization technology increasingly advances and the presence of the internet is increasingly needed in everyday life, both in socialization activities, education and business, including social media. Social media is a site where one can create personalized site pages and connect with everyone who is member of the same social media to share information and to communicate. Social networking sites are used because of their extensive connections with millions of users. They are a place for people to express their opinions on people, products or services. This is also one of the main reasons that raise the growth of users of social networking sites in recent years (Yap \& Lim, 2017; Liang \& Turban, 2011). No one can avoid on the development of social media entered in different layers of the society; its use is very diverse from business activities, education and government to enter the lifestyle. There has been a lot of empirical studies discussed the use of social media especially in the field of business transactions (Hariguna \& Berlilana, 2017).

\footnotetext{
* Corresponding author.

E-mail address: taqwa@amikompurwokerto.ac.id (T. Hariguna) 
The definition of social media is quite diverse. Social media is an online medium where its users can easily participate, share, and create content in the form of blogs, social networks, wikis, forums, and virtual worlds. The most common forms of social media used by people around the world today are Facebook, Instagram, Twitter, Whatapp, Youtube. Another opinion says that social media is an online medium that supports social interaction, and it uses web 2.0-based technology that can transform communication into interactive dialogue. The utilization is very diverse and the world of social media marketing is one effective business promotion tool because it can be accessed by anyone, so that the connection network becomes more widespread.

Many empirical studies have proven the use of social media to have a positive and significant impact on users, such as information retrieval (Xiang \& Gretzel, 2010), education (Mazman and Usluel, 2010), knowledge sharing or knowledge management (Chou et al., 2010), branding (Kim and Ko, 2012), egovernment (Kushin \& Yamamoto, 2010), and e-commerce (Hariguna and Berlilana, 2017). Quite a lot of studies discussed about social media and e-commerce along with the utilization and influence of information technology. According to Hu et al. (2006), e-commerce applications can cover many aspects of implementation, such as business to business, customer to customer or government to business. Social media is an important and even difficult part of e-commerce. So, nowadays the term social media commerce (s-commerce), refers to a combination of e-commerce activities that utilize social media application (Hariguna \& Berlilana, 2017). There are at least three features in terms of s-commerce advantages: 1) s-commerce usually uses applications that are already very popular among the public, such as Facebook and Instagram, so it is not difficult for vendors to gather prospective customers to introduce products to be offered. 2) the application used on s-commerce is free and not difficult to use, 3 ) after the process of buying and selling, customer transactions can provide feedback directly, and the results can be seen by other prospective customers, the element of openness and guarantee of products or service are the main things to be considered, because testimony from the customer will impact on what is offered by the vendor. This term is called customer experience (CE). CE is used to close the relationship between vendors with customers. This is an effort to ensure that customers feel comfortable after buying.

Focusing on $\mathrm{CE}$ from various studies that have been done, $\mathrm{CE}$ can be a competitive advantage for an organization or company. CE refers to sensory, emotional, and cognitive. This is based on the impact of the customer after a direct or observational experience that raises the customer's interest, motivates, and acknowledges, and can further add value or references to other customers (vonWallpach \& Kreuzer, 2013; Kim \& Perdue, 2013).

Customer experience has an important and contributing role to determine the success of a company (Yakhlef, 2015). Every effort made by the company will use the maximum service and provide good quality products, in order to get a satisfactory experience for the customer; it also affects the customer's subclass in the future (Chen \& Lin, 2015). Schmitt (1999), explains that CE is defined as a perception or recognition based on the motivation of consumers who observe or have felt in a real activity that can enrich the value of these services and products.

There have been many studies and scientific literature on CE. Over the last few decades, researchers have been interested in the development of social media that can provide value for business actors, especially in the field of s-commerce.

In addition, as the number of s-commerce activities is now increasing, it is certainly necessary to perceive or evaluate the activity, whether it has a positive impact or an inferior, expectation confirmation model is a theory that can provide views on post behavior and pre adoption; the merger between CE and ECM provide a meeting point between perception, theory and implementation. Especially with the advent of web 2.0 technology such experiences play an important role in influencing consumer preferences, which then impact consumer purchasing decisions. 
ECM is designed to identify factors affecting the sustainability of intent to use information technology, ECM in the adoption of two existing theories of expectation confirmation theory (ECT) and technology acceptance model (TAM). ECT is adopted to describe the theory of marketing while TAM is adopted to describe matters pertaining to information technology. In ECM there are four components namely expectation, perceived usefulness, satisfaction and behavior intention use. ECM has been used by many researchers because of its wide context and its model is well suited to use in post-expectation after a customer uses a service or a product.

In this research, this paper develops expectation confirmation model with customer experience, which in customer experience there are five supporting dimensions; namely sense, feel, think, act and relate. The purpose of this study is also to investigate the structural relationship between customer experience, expectation, perceived usefulness, satisfaction and behavioral intention to use s-commerce. Also, it aims to contribute to researchers and vendors in applying s-commerce and show that social media is a model that can increase profit and market share.

\section{Literature Review}

\subsection{Customer Experience}

$\mathrm{CE}$ is a model in marketing that follows customer equity. $\mathrm{CE}$ can be defined as an experience that is cognitive or perception of the customer from the results of observation and customer participation to what $\mathrm{s} /$ he finds in the real situation. Therefore, perception will improve customer ratings on the quality of products and services (Schmitt, 1999 \& 2012). For example, companies that provide intangible services or real-life products may create something that is easy to remember for the user in order to provide an impression or experience to his customers (Tsaur et al., 2007; Pine \& Gilmore, 1998). The dominant CE stimulant, with the presence of CE provides a deep psychological perception to its customers and will substantially influence the behavior of subsequent use in decision making (Hsu \& Tsou, 2011). In an effort to improve the $\mathrm{CE}$ in order to assist the marketing department to more easily identify market niches, it can be more effective than maintaining competitive market prices or improving existing product functionality and features (Kao et al., 2007). Schmitt (1999) developed an integrated CE framework to assist marketing to evaluate different types of experience (i.e., strategic experience). CE strategically regulates the implementation of customer experience with a product or company (Schmitt, 1999). Schmitt (1999) suggested that there are five types of CE as the basis for the overall marketing experience analysis; sense, feel, think, act and relate. CE is now important for more in-depth attention for service providers or product providers, because every experience felt by consumers is formed with a variety of different experiences. Vendors must be careful in handling and utilizing every experience to be used in accordance with the needs of their products. Social media not only deliver products or services to customers through sensing and feeling, but also provide affective, creative, cognitive, life style and sociality of the company or vendor experience to customers. Several studies have also examined the application of CE (Tsaur et al., 2007; Mason \& Paggiaro, 2012). However, research related to the application of CE on e-commerce in social media is still very limited. Therefore, this research seeks to examine the application of $\mathrm{CE}$ in s-commerce and its influence on other factors of the user's perception. The involvement of $\mathrm{CE}$ on customer satisfaction has a very significant role. Satisfaction is the view resulting from a process of experience with a positive value. When CE gives a positive impression to the customer it will have an impact on customer recognition and will increase the positive interaction (Kim, 2005); this can give a boost to the customer to make purchases and it will increase loyalty (Brakus et al., 2009). From the literature review above, then we propose the following hypothesis:

$\mathrm{H}_{1}$. Customer Experience has a positive influence on customer perceived usefulness.

$\mathrm{H}_{2}$. Customer Experience has a positive influence on customer satisfaction.

$\mathrm{H}_{3}$. Customer Experience has a positive influence on customer behavioral intention. 


\subsection{Expectation-Confirmation Model}

The expectation-confirmation model is a framework used by researchers to explain and understand matters relating to consumer satisfaction, trust and sustainability in purchasing or using a service (Fan \& Suh, 2014; Kim et al., 2009). Besides, some researchers explained that ECM is adopted to explain acceptance, use or adoption of a technology (Bhattacherjee, 2001; Bhattacherjee \& Premkumar, 2004; Halilovic \& Cicic, 2013; Stone \& Baker-Eveleth, 2013). ECM shows that consumer behavior in purchasing based on their own decisions, on the other hand, consumers will rely on their expectations of how well the services they receive. In addition, the information received by consumers with regard to the product or service will greatly affect the decision in purchasing; of course the information is expected to be accurate and reliable $(\mathrm{Wu}, 2013)$.

Meaning of expectation refers to how far the level of user satisfaction in feeling something, based on his experience using technology. Meanwhile, perceived usefulness is a feeling experienced by users to measure how far a person is believing the use of technology whether it is useful or not. Satisfaction is a positive emotional state resulting from the evaluation of the use of the technology, and continuance intention is useful as a reference to measure how far the customers intend to repurchase the technology or continue the use of the service (Bhattacherjee, 2001). If their expectations are met based on the use of such information technology, then the customers are likely to be satisfied and assume the technology is useful. In turn, customers tend to use technology continuously (Bhattacherjee, 2001).

\subsubsection{Customer Expectation Confirmation}

Expectation confirmation is a consumer decision derived from the facts that occur from the comparison before making a purchase by the customers. Expectation confirmation theory is widely proposed and empirically tested on the scope of IT/IS, marketing and e-government services (Anderson \& Sullivan, 1993; Bhattacherjee, 2001; Oliver, 1980; Hariguna et al., 2017; Hariguna \& Berlilana, 2017). In the context of e-commerce, in order to achieve customer satisfaction one of the main indicators that must be considered by the vendor is the expectation confirmation, this will greatly affect the formation of customer perceptions through transaction process. In addition, expectation confirmation on e-commerce transactions leads to the effect on customer satisfaction; there are services, goods and services. In other words if the vendor provides exceed customer expectations, it will result in positive confirmation, which will lead to the high level of customer satisfaction. Vice versa if the performance is considered worse than expectations, it will result in negative confirmation. This will result in low customer satisfaction. Thus we propose the following hypothesis:

$\mathrm{H}_{4}$ : Customer expectation confirmation has a positive influence on customer perceived usefulness.

$\mathrm{H}_{5}$ : Customer expectation confirmation has a positive influence on customer satisfaction.

\subsubsection{Customer perceived usefulness}

In ECM theory perceived usefulness is a user perception of the expected benefits of using IT/IS, as well as it is related to the performance aspects of IT/IS used (Davis, 1989; Bhattacherjee \& Premkumar, 2004; Venkatesh et al., 2011). Perceived usefulness serves as the motor of cognitive belief, which explains consistently that perceived usefulness affects the intent of the user in using IT/IS (Davis, 1989; Karahanna et al., 1999). It also positively impacts user satisfaction (Joo et al., 2017).

Customer perceived usefulness, is a way of view and experience perceived by the customers. There are two points of view assessment by the customers: positive and negative. Positive is a good assessment of the results of the process or experience felt during the s-commerce transaction, and vice versa. Some researchers have explained the positive impact of perceived usefulness on satisfaction and behavioral 
intention. We argue that the higher their perception of the benefits and usefulness of s-commerce activities is directly proportional to customer confidence and will have an impact on the entanglement for scommerce transactions.

Brown et al. (2012) explained that perceived usefulness is as an important determinant of the process of use on a system. In a study of online learning systems, other studies empirically assert that satisfaction and continuance intention are influenced by perceived usefulness (Liao et al., 2007). So we propose the following hypothesis:

$\mathrm{H}_{6}$. Customer perceived usefulness has a positive effect on customer behavior intention to use.

$\mathrm{H}_{7}$. Customer perceived usefulness has a positive effect on customer satisfaction.

\subsubsection{Customer satisfaction}

Satisfaction is a psychological state or feeling generated from the customer experience of his/her assessment of the experience (Oliver, 1980). In the field of information technology, it can be interpreted that satisfaction is referring to the results of the user experience in using information technology or information systems. Satisfaction has an important role in influencing the intention of a customer in determining whether s/he will use IT/IS in a long time (Bhattacherjee, 2001). The classic theory conveyed by Oliver (1980) that customer satisfaction influenced intentions in determining the survival of the next users. In another study Shi et al. (2010), explained satisfaction has a dominant role in determining the sustainability of Facebook usage. Recent research conducted by Hariguna and Beriliana (2017) showed that customer satisfaction had a positive impact on customer continue intention in e-commerce transactions in social media especially Facebook. Hence we propose the following hypothesis:

H8. Customer satisfaction has a positive effect on customer behavior intention.

Fig. 1 describes the research framework. The focus of this study is to use perceived usefulness, expectation confirmation and satisfaction to explain how customer experiments in s-commerce affect customer behavior intention use.

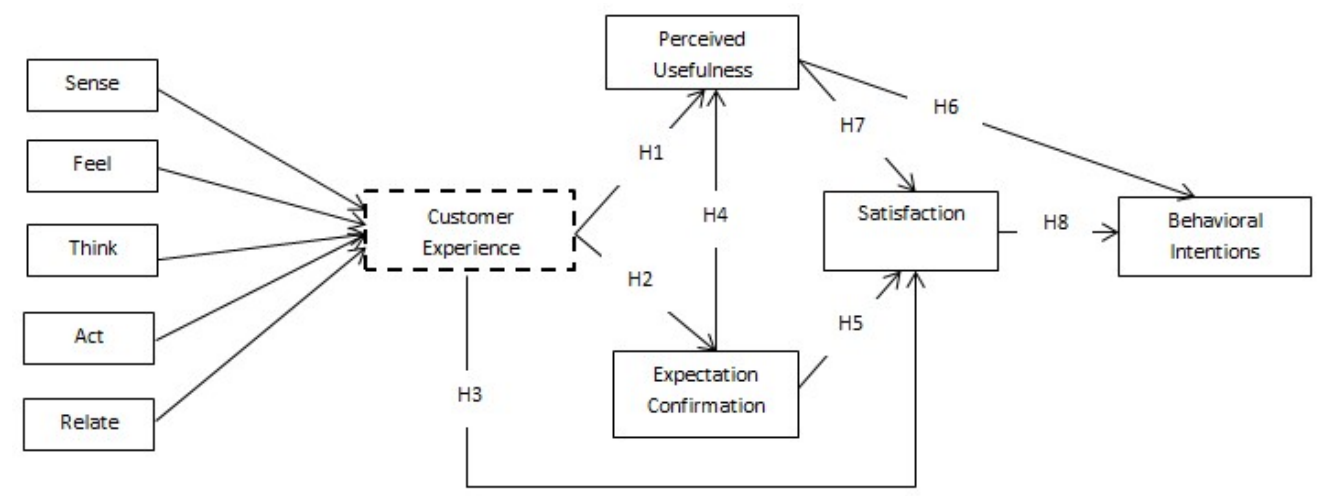

Fig. 1. Research framework

Second order formative construct

\section{Research method}

This research used quantitative method. Data taken using questionnaire method refers to previous research (Hariguna et al., 2017; Hariguna \& Berlilana, 2017). In this research we used seven Likert scales, besides the questionnaire used was divided into two parts; namely demographic information and amount 
of data used. To ensure that participants did not fill out the questionnaire more than once, each participant was asked to provide an e-mail address. Eliminating invalid responses has been done via data filtering. Valid final sampling was taken as many as 311 subjects. Table 1 presents sample demographic data. Measurement items were taken based on the aims of the previously mentioned research, through the research framework, as well as the relevant literature. The questionnaire was discussed with scholars who have expertise in marketing, information technology, social media behavior and have been revised several times following the pretest method. The questionnaire survey period was from 08 January 2019 to 30 March 2019.

\section{Table 1}

Demographics of the sample.

\begin{tabular}{lll}
\hline Characteristics & Frequency & Percent (\%) \\
\hline Gender & & 42.4 \\
$\quad$ Male & 132 & 57.6 \\
$\quad$ Female & 179 & 46.6 \\
\hline Age & & 31.2 \\
21-30 years old & 145 & 22.2 \\
\hline 41-40 years old & 97 & 39.5 \\
\hline Education level & 69 & 35.0 \\
$\quad$ High school certificate or lower degree & 123 & 25.4 \\
$\quad$ Undergraduate degree & 109 & 30.9 \\
$\quad$ Master or higher degree & 79 & 36.0 \\
\hline Experiences & & 33.1 \\
$\quad$ Less than 3 times/year & 96 & 112 \\
$\quad$ 3-5 time/year & 103 & \\
$\quad$ More than 5 time/year & & \\
\hline
\end{tabular}

\section{Results of the data analysis}

In this study we used SmartPLS 2.0 as a software to analyze data and to test hypotheses that have been made before. The technique used in PLS was structural equation modeling based on path analysis and regression analysis. Another reason to use PLS is that it can be used in analyzing models with two simultaneous indicator processes, namely reflective and formative, besides PLS can also be used to analyze data with large or small quantities, in addition to analyze complex predictive models, PLS can also help problems that are multi-collinearity. To measure the relationship between indicators and latent construction on PLS is called outer model. In addition, an inner model is used to measure the path structures between constructs (Kaufmann \& Gaeckler, 2015; Rezaei, 2015; Sarstedt et al., 2014).

In this study, the observed CE was the second-order formative measurement construct (Hair et al., 2017). To test the significance in this context, this study used the bootstrap method, which repeatedly retrieves and returns samples used to simulate random sample sizes. Suitable simulation samples were then used for evaluation and statistical testing. Based on suggestions proposed by Chin and Newsted (1999), the number of re-samples was set at 200 to achieve stable parameter estimates.

\subsection{Outer models}

In outer models, two fundamental things were tested: items construct and construct validity. Fornell and Larcker (1981) confirmed that the items construct used Cronbach $\alpha$ and composite reliability as a benchmark, where both values must be greater than 0.7 , so it was stated that the construction can be accepted and declared reliable. Meanwhile, in an effort to measure construct validity can be done with two methods that is by testing the convergent validity and discriminant validity. Still according to Fornell and Larcker (1981), who argued that a construction that can be stated has fulfilled convergent validity if the load factor of each indicator was worth at least 0.5 would be better if the value was greater. In addition, the value of the average variance extracted (AVE) of at least 0.5 would be better if the value was greater 
and the value of the composite reliability should be greater than 0.7 . Table 2 explains that factor loads, reliability tests and all constructions are in accordance with Fornell and Larcker's theory (1981). In addition to indicating that each construct can be stated to meet the requirements of discriminant validity then the root square of AVE must be greater than the correlation coefficient on each construct. Table 2 and 3 explain that the construct shows discriminant validity. In addition, to test the CE with secondorder formative measurement construct, as a benchmark is the convergent validity then the loading factor must be worth greater than 0.70 . To test the discriminant validity then the composite reliability and Cronbach alpha must be greater than or equal to 0.70 , while the validity test construct is done in bootstrapping process with t-value parameter bigger or equal to 1.95. From the above criteria, Table 2 explains that $\mathrm{CE}$ has been declared reliable and valid.

Table 2

Reliability analysis and convergent validity.

\begin{tabular}{|c|c|c|c|c|c|}
\hline Construct & $\begin{array}{l}\text { Measurement } \\
\text { items }\end{array}$ & $\begin{array}{l}\text { Factor } \\
\text { loading/coefficient/ }\end{array}$ & $\begin{array}{l}\text { Composite } \\
\text { reliability }\end{array}$ & AVE & Cronbach's $\alpha$ \\
\hline \multirow{5}{*}{ Customer Experience (CE) } & SEN & 8.37 & \multirow{5}{*}{ N.A } & \multirow{5}{*}{ N.A } & \multirow{5}{*}{ N.A } \\
\hline & FEL & 13.61 & & & \\
\hline & TNK & 18.53 & & & \\
\hline & $\mathrm{ACT}$ & 12.89 & & & \\
\hline & REL & 17.09 & & & \\
\hline \multirow[t]{2}{*}{ Sense experience (SEN) } & SEN1 & 0.74 & \multirow{2}{*}{0.78} & \multirow{2}{*}{0.82} & \multirow{2}{*}{0.85} \\
\hline & SEN2 & 0.85 & & & \\
\hline \multirow[t]{2}{*}{ Feel experience (FEL) } & FEL1 & 0.85 & \multirow{2}{*}{0.71} & \multirow{2}{*}{0.71} & \multirow{2}{*}{0.79} \\
\hline & FEL2 & 0.82 & & & \\
\hline \multirow{2}{*}{ Think experience (TNK) } & TNK1 & 0.86 & \multirow{2}{*}{0.83} & \multirow{2}{*}{0.83} & \multirow{2}{*}{0.83} \\
\hline & TNK2 & 0.84 & & & \\
\hline \multirow{2}{*}{ Act experience (ACT) } & ACT1 & 0.90 & \multirow{2}{*}{0.91} & \multirow{2}{*}{0.83} & \multirow{2}{*}{0.85} \\
\hline & $\mathrm{ACT} 2$ & 0.92 & & & \\
\hline \multirow[t]{2}{*}{ Relate experience (REL) } & REL1 & 0.86 & \multirow{2}{*}{0.82} & \multirow{2}{*}{0.70} & \multirow{2}{*}{0.76} \\
\hline & REL2 & 0.80 & & & \\
\hline \multirow{3}{*}{ Perceived Usefulness (PU) } & PU1 & 0.91 & \multirow[b]{3}{*}{0.87} & \multirow[b]{3}{*}{0.69} & \multirow[b]{3}{*}{0.77} \\
\hline & PU2 & 0.76 & & & \\
\hline & PU3 & 0.80 & & & \\
\hline \multirow{3}{*}{ Expectation Confirmation (EC) } & EC1 & 0.87 & \multirow[b]{3}{*}{0.85} & \multirow{4}{*}{0.65} & \multirow[b]{3}{*}{0.73} \\
\hline & $\mathrm{EC} 2$ & 0.82 & & & \\
\hline & EC3 & 0.70 & & & \\
\hline \multirow{3}{*}{ Customer Satisfaction (CS) } & CS1 & 0.88 & & & \\
\hline & CS2 & 0.83 & & & \\
\hline & $\mathrm{CS} 3$ & 0.68 & 0.85 & 0.65 & 0.73 \\
\hline Behavior Intention (BI) & BI1 & 0.83 & 0.85 & 0.73 & 0.74 \\
\hline & $\mathrm{BI} 2$ & 0.87 & & & \\
\hline
\end{tabular}

Table 3

Correlation matrix.

\begin{tabular}{lllll}
\hline & BI & CE & CS & PU \\
\hline BI & 0.856 & & & \\
CE & 0.748 & 0.805 & 0.805 & 0.829 \\
CS & 0.698 & 0.768 & 0.764 & \\
\hline PU & 0.718 & 0.751 & .
\end{tabular}

Note: perceived usefulness (PU); customer satisfaction (CS); expectation confirmation (EC); behavior intention (BI).

4.2 Inner model

In PLS to measure the significance of the benchmark hypothesis used is the path coefficient t-values, in table 4 describes the results of all hypotheses of significant and positive value. Figure 2 also illustrates the results of the hypothesis. 
Table 4

Summary of hypotheses testing results.

\begin{tabular}{lllrr}
\hline Hypothesis & Path & $\begin{array}{l}\text { Standardized } \\
\text { path coefficient }\end{array}$ & t-value & Supported \\
\hline H1 & CE-PU & $0.27 * * *$ & 8.67 & Yes \\
H2 & CE-EC & $0.80^{* * *}$ & 18.10 & Yes \\
H3 & CE-CS & $0.47^{* * *}$ & 8.45 & Yes \\
H4 & EC-PU & $0.70^{* * *}$ & 14.17 & Yes \\
H5 & EC-CS & $0.22^{* * *}$ & 2.85 & Yes \\
H6 & PU-BI & $0.45^{* * *}$ & 4.61 & Yes \\
H7 & PU-CS & $0.25^{* * *}$ & 2.86 & Yes \\
H8 & CS-BI & $0.30^{* * *}$ & 3.02 & Yes \\
\hline
\end{tabular}

Note 1: customer experiences (CE); perceived usefulness (PU); customer satisfaction (CS); expectation confirmation (EC); behavior intention (BI).

Note $2: * * *$ p-value $<0.001$

\subsection{Testing of mediation effects}

In this study there were three mediation effects that must be tested, to test the significance of all three used Sobel test to analyze, where to get a significant value then z-value must be worth 1.96 or more (MacKinnon et al., 2007; Sobel, 1982). In this study, we found that all meet the criteria and significant value, as shown in Table 5.

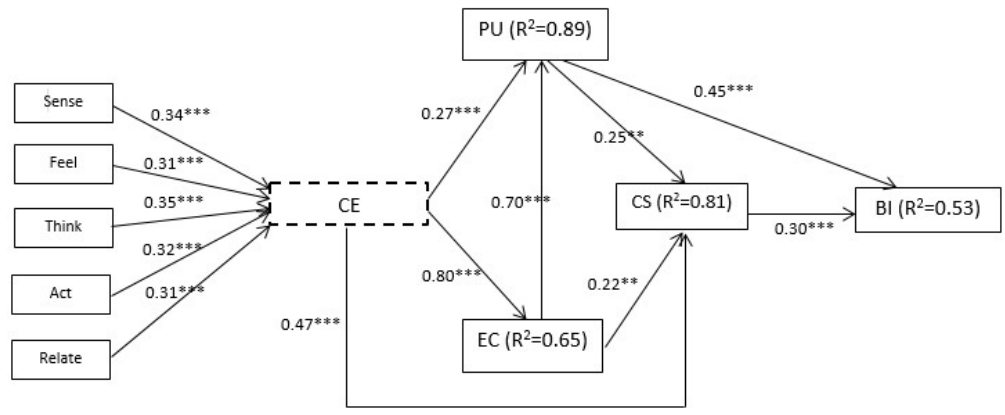

Fig. 2. Inner model and path coefficient.

Note 1: customer experiences (CE); perceived usefulness (PU); customer satisfaction (CS); expectation confirmation (EC); behavior intention (BI). Note $2: * *$ p-value $<0.01,{ }^{* * *}$-value $<0.001$

Table 5

Mediation effects testing

\begin{tabular}{|c|c|c|c|c|c|}
\hline Constructs & $\begin{array}{c}\text { Construct } \\
\text { relationships }\end{array}$ & $\begin{array}{l}\text { Standardized path } \\
\text { coefficients }\end{array}$ & Standard error & $\begin{array}{l}\text { T-value of path } \\
\text { coefficients }\end{array}$ & $\begin{array}{c}\text { Sobel test's } \\
\text { z-value }\end{array}$ \\
\hline \multirow{2}{*}{ CE-PU-CS } & CE-PU & 0.27 & 0.031142 & 8.67 & \multirow{2}{*}{$2.71 * * *$} \\
\hline & PU-CS & 0.25 & 0.087413 & 2.86 & \\
\hline \multirow{2}{*}{ CE-PU-BI } & CE-PU & 0.27 & 0.031142 & 8.67 & \multirow{2}{*}{$4.07 * * *$} \\
\hline & PU-BI & 0.45 & 0.097614 & 4.61 & \\
\hline \multirow{2}{*}{ CE-CS-BI } & CE-CS & 0.47 & 0.055621 & 8.45 & \multirow{2}{*}{$2.84 * * *$} \\
\hline & CS-BI & 0.30 & 0.099338 & 3.02 & \\
\hline \multirow{2}{*}{ CE-EC-PU } & CE-EC & 0.80 & 0.044199 & 18.1 & \multirow{2}{*}{$11.15^{* * *}$} \\
\hline & EC-PU & 0.70 & 0.049400 & 14.17 & \\
\hline \multirow{2}{*}{ CE-EC-CS } & CE-EC & 0.80 & 0.044199 & 18.1 & \multirow{2}{*}{$2.81 * * *$} \\
\hline & EC-CS & 0.22 & 0.077193 & 2.85 & \\
\hline \multirow{2}{*}{ EC-CS-BI } & EC-CS & 0.22 & 0.077193 & 2.85 & \multirow{2}{*}{$2.07^{* *}$} \\
\hline & CS-BI & 0.31 & 0.102649 & 3.02 & \\
\hline \multirow{2}{*}{ EC-PU-CS } & EC-PU & 0.70 & 0.049400 & 14.17 & \multirow{2}{*}{$2.80 * * *$} \\
\hline & PU-CS & 0.25 & 0.087413 & 2.86 & \\
\hline \multirow{2}{*}{ EC-PU-BI } & EC-PU & 0.70 & 0.049400 & 14.17 & \multirow{2}{*}{$4.38^{* * *}$} \\
\hline & PU-BI & 0.45 & 0.097614 & 4.61 & \\
\hline \multirow{2}{*}{ EC-CS-BI } & EC-CS & 0.22 & 0.077193 & 2.85 & \multirow{2}{*}{$2.07 * *$} \\
\hline & CS-BI & 0.30 & 0.099338 & 3.02 & \\
\hline
\end{tabular}

Note 1: customer experiences (CE); perceived usefulness (PU); customer satisfaction (CS); expectation confirmation (EC); behavior intention (BI).

Note $2: * *$ p-value $<0.01, * * *$ p-value $<0.001$ 


\section{Discussion}

This research can be used for researchers and practitioners in marketing, s-commerce and vendors. Based on the results of $\mathrm{H}_{1}, \mathrm{H}_{2}$ and $\mathrm{H}_{3}, \mathrm{CE}$ on s-commerce positively and significantly affect PU, EC and satisfaction. Similarly, CE in s-commerce shows that it indirectly affects the satisfaction and BI. CE is closely related to conventional marketing methods in which conventional marketing, customer behavior and emotional reactions will influence their decisions in action. This will provide psychologist results or evaluation for users and even generate positive or negative perceptions. Similarly, in s-commerce customer interaction will result in reference and evaluation of psychological CE; even by looking and listening to the testimony result can also provide additional experience. Layout and product design in the show will give stimulus to customer expectation and satisfaction. Thus the customer will be more steady towards the services provided, thus strengthening customer intentions. Nowadays, in the presence of scommerce vendors should provide information about the products offered well, testimonials from other customers will very easily become viral.

Based on the results of the analysis for $\mathrm{H}_{4}$ and $\mathrm{H}_{5}$, we have found that customer expectation was an inseparable experience in the processes that occured in s-commerce, and was an underlying part of customer satisfaction and customer perceived usefulness perception directly. On the other hand, it indirectly had a positive and significant impact on BI. This study confirmed that PU customers in s-commerce positively and significantly affected satisfaction and $\mathrm{BI}\left(\mathrm{H}_{6}\right.$ and $\mathrm{H}_{7}$ are both supported). From a practical perspective, when customers cognitively feel the great benefits to the system offered, the customer will be loyal to what is offered by the vendor and can occur in a long time that is real, and the customer will be emotionally bound and of course this will impact on satisfaction and BI. The deep concern is how vendors can provide a positive experience for shaping PU in their customers. PU provides the foundation of satisfaction and CI in s-commerce in the long term. Customers who get what is expected after the activity on s-commerce will produce a positive experience and will provide positive testimonials for other customers, this will impact on tight customer relationship with vendors, of course, and will impact on customer satisfaction and PU. Furthermore, this research found that customer satisfaction in s-commerce positively and significantly influence to customer $\mathrm{BI}\left(\mathrm{H}_{8}\right.$ supported). Customer satisfaction in scommerce affects BI. Over time, emotional relationships between customers and vendors will occur. This relationship will last long if customer satisfaction can be maintained well. Loyalty from the customer will be built by itself if this ridge can be established stable and sustainable.

This study aims to measure the impact of s-commerce. In addition, we have modified ECM with CE. Our research used empirical approach of ECM model consisting of PU, EC, CS and BI. They have been studied and analyzed carefully with correlation to each other, besides CE which consists of five dimensions namely sense, feel, think, act, relate have also been proposed to complement the perfection of the theory of s-commerce. This study refers to research that has been done by previous researchers (Hariguna et al., 2017). This research gives a real contribution to the researcher in the field of s-commerce, it also contributes to the vendor to pay more attention to $\mathrm{CE}$ to get $\mathrm{CS}$ and $\mathrm{BI}$.

\section{Conclusion}

Theoretically this research can be used as a reference for researchers who conduct research in marketing, consumer behavior and interaction in s-commerce. We have explained how the role of CE can give value to the s-commerce activity. In addition, this research has provided an overview of ECM theory that can be synergized with $\mathrm{CE}$, which in previous studies has not yet discussed the merging of those implemented in the case of s-commerce. Then the practical implication, we can conclude that the research we was performed to contribute to the actors of s-commerce activities as well as to provide a framework forward in conducting business activities in the world of social media, because s-commerce has unique values or difference than the conventional way. In addition to this research we emphasize for practitioners to really maintain customer satisfaction during the transaction process of s-commerce. 
Consumer behavior is always dynamic so that s-commerce providers should be alert to capture consumer needs and s-commerce providers must adapt existing content and methods. Thus, this study has examined the impact of CE on PU and EC. We have also examined the effect of this impact on customer satisfaction on s-commerce and customer BI. Based on empirical data, the contribution of this research is that we have developed an s-commerce model to explain and predict relationships between users and vendors. Results can be a reference for practitioners who are trying to build a business in the field of scommerce. In addition, we introduce $\mathrm{CE}$ in order to become one of the focuses for practitioners in building s-commerce.

Research on CE is widely adopted in order to strengthen marketing and is the key to success (Tsaur et al., 2007; Pine \& Gilmore, 1998; Schmitt, 2012). Currently the customer does not really care about things that are technical like the stability of a system, but the customer will be very focused on experience, testimonials and expectations.

This study investigated and analyzed how customer can manage BI on s-commerce through the CE concept. The $\mathrm{CE}$ in this study we presented in formative construction form has been done by previous researchers. CE presented involved five dimensions of sense, feel, think, act, and relate. In this study we have concluded that $\mathrm{CE}$ could be a significant marketing method in s-commerce. In the process of customer interaction with $\mathrm{CE}$, vendors can increase interest in s-commerce and motivate decision-making. The use of social media in recent years has expanded the methods of marketing and conventional business transactions. Now information from social media is faster than other conventional media, without space limits, distance and time. S-commerce is one of the existing positive impacts of social media, scommerce designed using $\mathrm{CE}$ will be able to provide significant added value for BI. In addition, this research is to analyze the effect of $\mathrm{CE}$ on PU, EC and customer satisfaction. Then the next discussion will be about how the relationship between customer and vendor to be maintained properly. The findings in this study can be used as a reference for academic and practitioners in establishing customer relationships on a sustainable, long-term and sustainable s-commerce. The s-commerce vendors should consider how to build customer satisfaction sourced from various types of CE.

This research has tested the perception of customer to s-commerce as market share media. The survey area used is Indonesian; the model adopted in this research is ECM and modification with CE. Empirically this ECM method has been valid and verified by many researchers. It can be used to assess the behavior and perception of customer in e-government service, e-commerce and e-learning. Of the eight hypotheses we proposed, it has resulted that the overall hypothesis is positive.

\section{References}

Anderson, E. W., \& Sullivan, M. W. (1993). The antecedents and consequences of customer satisfaction for firms. Marketing science, 12(2), 125-143.

Bhattacherjee, A. (2001). Understanding information systems continuance: an expectation-confirmation model. MIS Quarterly, 25, 351-370.

Bhattacherjee, A., \& Premkumar, G. (2004). Understanding changes in belief and attitude toward information technology usage: A theoretical model and longitudinal test. MIS quarterly, 28, 229-254.

Brown, S. A., Venkatesh, V., \& Goyal, S. (2012). Expectation confirmation in technology use. Information Systems Research, 23(2), 474-487.

Chen, S. C., \& Lin, C. P. (2015). The impact of customer experience and perceived value on sustainable social relationship in blogs: An empirical study. Technological Forecasting and Social Change, 96, 40-50.

Chin, W. W., \& Newsted, P. R. (1999). Structural equation modeling analysis with small samples using partial least squares. Statistical strategies for small sample research, 1(1), 307-341.

Chou, S. W., Min, H. T., Chang, Y. C., \& Lin, C. T. (2010). Understanding continuance intention of knowledge creation using extended expectation-confirmation theory: an empirical study of Taiwan and China online communities. Behaviour \& Information Technology, 29(6), 557-570. 
Davis, F. D. (1989). Perceived usefulness, perceived ease of use, and user acceptance of information technology. MIS Quarterly, 13(3), 319-340.

Fan, L., \& Suh, Y. H. (2014). Why do users switch to a disruptive technology? An empirical study based on expectation-disconfirmation theory. Information \& Management, 51(2), 240-248.

Fornell, C., \& Larcker, D.F. (1981). Evaluating structural equation models with unobservable variables and measurement error. Journal of Marketing Research, 18(1), 39-50.

Hair, J. F., Hult, G. T. M., Ringle, C. M., \& Sarstedt, M. (2017). A primer on partial least squares structural equation modeling (PLS-SEM)(2nd ed.). Thousand Oaks: Sage Publications.

Halilovic, S., \& Cicic, M. (2013). Antecedents of information systems user behaviour-extended expectation-confirmation model. Behaviour \& Information Technology, 32(4), 359-370.

Hariguna, T., \& Berlilana, B. (2017). Understanding of Antecedents to Achieve Customer Trust and Customer Intention to Purchase E-Commerce in Social Media, an Empirical Assessment. International Journal of Electrical and Computer Engineering, 7(3), 1240.

Hariguna, T., Lai, M. T., Hung, C. W., \& Chen, S. C. (2017). Understanding information system quality on public e-government service intention: an empirical study. International Journal of Innovation and Sustainable Development, 11(2-3), 271-290.

Hsu, H. Y., \& Tsou, H. T. (2011). Understanding customer experiences in online blog environments. International Journal of Information Management, 31(6), 510-523.

Hu, W. C., Yeh, J. H., Fu, L., \& Yang, H. J. (2007). Handheld Computing and Programming for Mobile Commerce. International Journal of Web Information Systems, 2(3/4), 164-175.

Joo, Y. J., Park, S., \& Shin, E. K. (2017). Students' expectation, satisfaction, and continuance intention to use digital textbooks. Computers in Human Behavior, 69, 83-90.

Karahanna, E., Straub, D. W., \& Chervany, N. L. (1999). Information technology adoption across time: a cross-sectional comparison of pre-adoption and post-adoption beliefs. MIS quarterly, 6 183-213.

Kaufmann, L., \& Gaeckler, J. (2015). A structured review of partial least squares in supply chain management research. Journal of Purchasing and Supply Management, 21(4), 259-272.

Kao, Y. F., Huang, L. S., \& Yang, M. H. (2007). Effects of experiential elements on experiential satisfaction and loyalty intentions: a case study of the super basketball league in Taiwan. International Journal of Revenue Management, 1(1), 79-96.

Kim, A. J., \& Ko, E. (2012). Do social media marketing activities enhance customer equity? An empirical study of luxury fashion brand. Journal of Business research, 65(10), 1480-1486.

Kim, D., \& Perdue, R. R. (2013). The effects of cognitive, affective, and sensory attributes on hotel choice. International Journal of Hospitality Management, 35, 246-257.

Kim, D. J., Ferrin, D. L., \& Rao, H. R. (2009). Trust and satisfaction, two stepping stones for successful e-commerce relationships: A longitudinal exploration. Information systems research, 20(2), 237-257.

Kushin, M. J., \& Yamamoto, M. (2010). Did social media really matter? College students' use of online media and political decision making in the 2008 election. Mass Communication and Society, 13(5), 608-630.

Liang, T. P., \& Turban, E. (2011). Introduction to the special issue social commerce: a research framework for social commerce. International Journal of electronic commerce, 16(2), 5-14.

Liao, C., Chen, J. L., \& Yen, D. C. (2007). Theory of planning behavior (TPB) and customer satisfaction in the continued use of e-service: An integrated model. Computers in human behavior, 23(6), 28042822.

MacKinnon, D. P., Fritz, M. S., Williams, J., \& Lockwood, C. M. (2007). Distribution of the product confidence limits for the indirect effect: Program PRODCLIN. Behavior Research Methods, 39(3), 384-389.

Mason, M. C., \& Paggiaro, A. (2012). Investigating the role of festivalscape in culinary tourism: The case of food and wine events. Tourism management, 33(6), 1329-1336.

Mazman, S. G., \& Usluel, Y. K. (2010). Modeling educational usage of Facebook. Computers \& Education, 55(2), 444-453.

Oliver, R. L. (1980). A cognitive model of the antecedents and consequences of satisfaction decisions. Journal of Marketing Research, 17(4), 460-469. 
Pine, B.J., \& Gilmore, J.H. (1998). Welcome to the experience economy. Harvard Business Review, 76, 97-105.

Rezaei, S. (2015). Segmenting consumer decision-making styles (CDMS) toward marketing practice: a partial least squares (PLS) path modeling approach. Journal of Retailing and Consumer Services, 22, $1-15$.

Sarstedt, M., Ringle, C. M., Smith, D., Reams, R., \& Hair Jr, J. F. (2014). Partial least squares structural equation modeling (PLS-SEM): A useful tool for family business researchers. Journal of Family Business Strategy, 5(1), 105-115.

Schmitt, B.H. (1999). Experiential marketing: how to get customers to sense, feel, think, act and relate to your company and brand. New York.

Schmitt, B.H. (2012). The consumer psychology of brands. Journal of Consumer Psychology, 22, 7-17.

Shi, N., Lee, M. K., Cheung, C. M., \& Chen, H. (2010, January). The continuance of online social networks: how to keep people using Facebook?. In 2010 43rd Hawaii International Conference on System Sciences (pp. 1-10). IEEE.

Sobel, M. E. (1982). Asymptotic confidence intervals for indirect effects in structural equation models. Sociological methodology, 13, 290-312.

Stone, R. W., \& Baker-Eveleth, L. (2013). Students' expectation, confirmation, and continuance intention to use electronic textbooks. Computers in Human Behavior, 29(3), 984-990.

Tsaur, S. H., Chiu, Y. T., \& Wang, C. H. (2007). The visitors behavioral consequences of experiential marketing: An empirical study on Taipei Zoo. Journal of Travel \& Tourism Marketing, 21(1), 47-64.

Von Wallpach, S., \& Kreuzer, M. (2013). Multi-sensory sculpting (MSS): Eliciting embodied brand knowledge via multi-sensory metaphors. Journal of Business Research, 66(9), 1325-1331.

$\mathrm{Wu}$, I. L. (2013). The antecedents of customer satisfaction and its link to complaint intentions in online shopping: An integration of justice, technology, and trust. International Journal of Information Management, 33(1), 166-176.

Xiang, Z., \& Gretzel, U. (2010). Role of social media in online travel information search. Tourism Management, 31, 179-188.

Yakhlef, A. (2015). Customer experience within retail environments an embodied, spatial approach. Marketing Theory, 15(4), 545-564.

Yap, H. Y., \& Lim, T.-M. (2017). Social trust: impacts on social influential diffusion. International Journal of Web Information Systems, 13(2), 199-219.

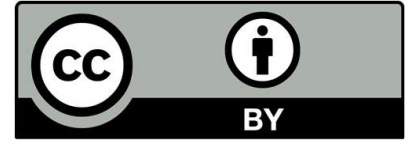

(C) 2019 by the authors; licensee Growing Science, Canada. This is an open access article distributed under the terms and conditions of the Creative Commons Attribution (CCBY) license (http://creativecommons.org/licenses/by/4.0/). 